Tsaqofiya : Jurnal Pendidikan Bahasa dan Sastra Arab

Vol. 3 No. 1, 2021, 26-45

P-ISSN : 2685-7022, E-ISSN : 2685-7103

DOI: $10.21154 /$ tsaqofiya.v3i1.66

\title{
Pengembangan Buku Ajar Bahasa Arab Berbasis pada Nilai-Nilai Islam- Indonesia di IAIN Salatiga
}

\author{
Burhan Yusuf Habibi', Wakhidati Nurrohmah Putri² \\ ${ }^{1}$ IAIN Salatiga, ${ }^{2}$ IAIN Salatiga \\ 1. burhanyusufhabibi@iainsalatiga.ac.id,2wakhidputri@gmail.com
}

\section{Abstract}

This study aims to develop Arabic language teaching materials 1 based on IslamicIndonesian values at the State Islamic Institute of Slaatiga. This research is motivated by the lack of specific teaching materials for this course after transferring status from STAIN to IAIN and learning Arabic was returned to the faculty. This research is a type of research and development with the Borg \& Gall development model. The analysis technique in this study uses quantitative descriptive techniques. The results showed that the results of student responses to the Arabic Textbook 1 Based on Islamic-Indonesian Values at the Salatiga State Islamic Institute which was developed viewed from the learning aspect obtained an average score of 4.025, the content or material aspect with an average score average 4.095, aspects of the display with an average score of 4.098 and aspects of the presentation with an average score of 4.08, then the overall average score is 4.075. Thus, Arabic textbook based on Islamic-Indonesian values is worthy of being used as teaching material in the Arabic language course 1 at the Salatiga State Islamic Institute.

Keywords: Developing Teaching Materials, Arabic Language, Islamic-Indonesian Values

\section{Abstrak}

Penelitian ini bertujuan untuk mengembangkan bahan ajar Bahasa Arab bebasis pada nilai-nilai Islam-Indonesia di IAIN Salatiga. Penelitian ini dilatarbelakangi belum adanya bahan ajar khusus untuk mata kuliah ini setelah alih status dari STAIN ke IAIN, dan pembelajaran bahasa Arab dikembalikan ke fakultas. Penelitian ini merupakan jenis penelitian dan pengembangan dengan model pengembangan Borg \& Gall. Teknik analisis dalam penelitian ini menggunakan teknik deskriptif kuantitatif. Hasil penelitian menunjukkan bahwa hasil respon atau tanggapan mahasiswa terhadap Buku Ajar Bahasa Arab Berbasis pada Nilai-Nilai IslamIndonesia di IAIN Salatiga yang dikembangkan dilihat dari aspek pembelajaran memperoleh skor rata-rata 4,025, aspek isi/materi dengan skor rata-rata 4,095, aspek tampilan dengan skor rata-rata 4,098 dan aspek penyajian dengan skor ratarata 4,08, maka rerata skor secara keseluruhan adalah 4,075. Dengan demikian, buku ajar Bahasa Arab berbasis pada nilai-nilai Islam-Indonesia ini layak digunakan sebagai bahan ajar dalam mata kuliah Bahasa Arab di IAIN Salatiga.

Kata Kunci: Pengembahan Bahan Ajar, Bahasa Arab, Nilai-Nilai Islam-Indonesia 
TSAQOFIYA: Jurnal Pendidikan Bahasa dan Sastra, 3 (1), 2021

\section{Pendahuluan}

Bahasa Arab telah menjadi bahasa ilmiah, akademis, dan sekaligus bahasa populer masyarakat internasional. Dengan demikian mempelajari bahasa Arab sebagai alat menyampaikan kebenaran ilmu pengetahuan, dengan sendirinya menjadi sangat penting. Dalam perspektif ini, Perguruan Tinggi Keagamaan Islam (PTKI) yang menggunakan bahasa Arab sebagai alat untuk memahami teks asli ajaran agama maupun alat komunikasi bagi civitas akademikanya, hendaknya melihat bahasa Arab juga secara fungsional.

Semua orang yang belajar atau mengajar di perguruan tinggi Islam khususnya, sudah semestinya mengerti, memahami dan menguasai bahasa Arab. Bahkan untuk perguruan tinggi umum sekalipun dalam kasus mata kuliah dan literatur tertentu yang menggunakan bahasa Arab, maka dengan sendirinya harus mengetahui dan harus menguasai bahasa Arab tersebut. Oleh karena itu, sangat ironis memang, kalau ada Perguruan Tinggi Agama Islam yang di dalamnya tidak ada nuansa Arabnya, apalagi civitas akademikanya tidak diwajibkan untuk menggunakan bahasa Arab sebagaimana diwajibkannya bahasa yang lainnya.

Hanya saja pembelajaran bahasa Arab di PTKI masih banyak yang menggunakan metode tradisional yang kebanyakan masih fokus kepada kaidahkaidah bahasa dan menterjemah serta mengajarkan bahasa Arab secara parsial dan tidak melihat perkembangan dan kebutuhan zaman. Hal ini juga terjadi di Institut Agama Islam Negeri (IAIN Salatiga). Pengembangan bahasa Arab masih berkutat pada metode dan cara tradisional, yakni untuk tujuan-tujuan keagamaan dengan penekanan materi pada aspek penguasaan kaidah-kaidah Bahasa Arab.

Sebelum beralih status dari Sekolah Tinggi Agama Islam Negeri (STAIN), IAIN Salatiga melaksanakan program Sistem Intensif Bahasa Arab (Siba) yang dikelola oleh Unit Pengembangan Bahasa (UPB). Buku ajar yang digunakan adalah perpaduan antara Al-Arabiyyah li An-Nasyiin dan Al-Arabiyyah Baina Yadaik. Program ini berjalan selama 1 tahun dengan 4 SKS setiap semesternya. Dengan adanya program ini, pembelajaran Bahasa Arab benar-benar dikembangkan dengan sIstem intensif dengan buku ajar yang jelas. Akan tetapi, pasca alih status menjadi IAIN, sudah tidak ada lagi program Siba dan Bahasa Arab dikembalikan pengelolaannya ke Fakultas menjadi mata kuliah tersendiri dengan masing-masing semester 2 SKS. 
TSAQOFIYA: Jurnal Pendidikan Bahasa dan Sastra, 3 (1), 2021

Perubahan itu, tidak diiringi dengan adanya penyusunan kurikulum Bahasa Arab yang jelas dengan standar-standar yang disepakati bersama. Silabus yang ada masih memberikan porsi yang sangat besar terhadap kaidah-kaidah Bahasa Arab daripada kemampuan yang lain. Selain itu, tidak ada buku ajar yang baku sebagai pegangan dosen maupun mahasiswa.

Sebelum alih status, buku ajar yang sebelumnya digunakan merupakan buku ajar yang berasal dari negara timur tengah, seperti al-'Arabiyyah li an-Nâsyi'în dan al'Arabiyah baina Yadaik. Meskipun didesain khusus untuk non-Arab (lighairi annâthiqîna bihâ), materi-materi, tema-tema dan kosakata-kosata yang ada pada bukubuku itu masih jauh dari kehidupan nyata peserta didik atau mahasiswa. Budaya dan bahan bacaannya juga masih terlalu Arab Sentris dan belum menggunakan pendekatan keIndonesiaan sehingga lebih dekat dan menarik bagi mahasiswa.

Dengan adanya fenomena di atas, maka perlu adanya upaya pengembangan buku ajar mata kuliah Bahasa Arab di IAIN Salatiga berbasis nilai-nilai IslamIndonesia yang kemudian bisa ditindaklanjuti dengan pengembangan bahan ajar untuk mata kuliah Bahasa Arab. Oleh karena itu, penelitian pengembangan untuk menghasilkan buku ajar mata kuliah Bahasa Arab di IAIN Salatiga sangat penting untuk dilakukan.

\section{Metode}

Penelitian ini menggunakan metode Research and Development (R\&D).Metode penelitian dan pengembangan adalah metode penelitian yang digunakan untuk menghasilkan produk tertentu dan menguji keefektifan produk tersebut ${ }^{1}$. Tujuan utama dari penelitian ini adalah untuk mengembangkan produk efektif yang digunakan di sekolah. Hal ini sesuai dengan pendapat yang dikemukakan oleh Borg and Gall yaitu "Education research and development (R\&D) is a process used to develop and validate educational products" 2 . Produk yang dimaksud Borg dan Gall berupa buku teks, film, software, komputer, metode, dan program.

Model pengembangan dalam penelitian ini adalah model pengembangan Borg \& Gall yang dapat dilihat dalam bagan I sebagai berikut ${ }^{3}$ : 2010).

1Prof Dr Sugiyono, Metode Penelitian Kuantitatif, Kualitatif Dan $R$ \& D, Alfabeta (Bandung,

${ }^{2}$ M.D Borg, W.R. and Gall, Education Research: An Introduction (London: Longman, Inc, 1983). 3Teun Adrianus Van Dijk and Walter Kintsch, "Strategies of Discourse Comprehension," 1983. 


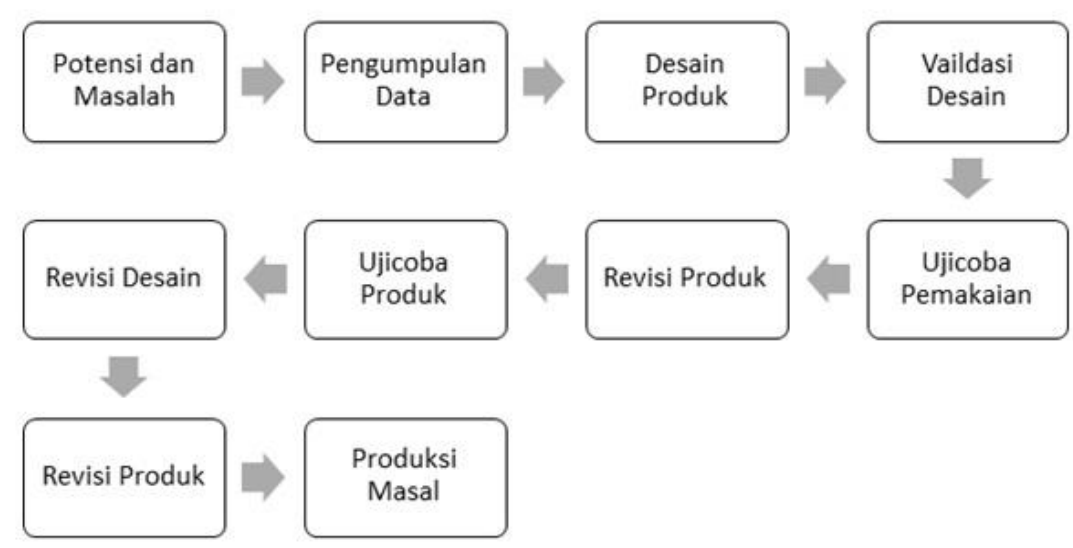

Penelitian ini mengambil lokasi di IAIN Salatiga yang mana Bahasa Arab menjadi mata kuliah dasar wajib bagi seluruh mahasiswa baru. Berdasarkan penelitian awal, belum ada buku ajar baku yang digunakan untuk mata kuliah Bahasa Arab.

Subjek dalam penelitian ini adalah Mahasiswa baru IAIN Salatiga tahun ajaran 2020/2021. Sampel dalam penelitian ini 50 mahasiswa. Teknik Sampling yang digunakan dalam penelitian ini adalah random sampling (mengambil sampel secara acak).

Objek penelitian sama dengan variabel yaitu apa yang menjadi titik perhatian suatu penelitian. Obyek dalam penelitian ini adalah pengembangan buku ajar Bahasa Arab berbasis pada nilai-nilai Islam Indonesia di IAIN Salatiga.

Untuk mengetahui kualitas produk yang dikembangkan, maka diperlukan data kuantitatif berupa skor tanggapan tentang kualitas produk dari ahli materi pembelajaran dan ahli media serta mahasiswa. Skor penilaian tentang kualitas produk dari ahli materi pembelajaran meliputi aspek pembelajaran dan aspek isi/materi. Skor penilaian dari ahli media meliputi aspek efektifitas dan penyajian. Skor penilaian dari mahasiswa meliputi aspek pembelajaran, aspek isi/materi, aspek efektifitas dan aspek penyajian ${ }^{4}$.

Instrument yang digunakan untuk mengumpulkan data pada penelitian ini berupa angket. Angket digunakan untuk mengumpulkan data-data kuantitatif. Datadata ini digunakan untuk mengetahui kelayakan produk yang dikembangkan.

${ }^{4}$ A. Prastowo, Pengembangan Bahan Ajar Tematik (Jakarta: Kencana Predanamedia Group, 
TSAQOFIYA: Jurnal Pendidikan Bahasa dan Sastra, 3 (1), 2021

Teknik analisis dalam penelitian ini menggunakan teknik deskriptif kuantitatif .Data yang diperoleh melalui angket dari ahli materi pembelajaran dan ahli media serta mahasiswa terhadap produk yang dikembangkan kemudian dianalisis. Langkahlangkah yang digunakan dalam analisis data untuk memberikan kriteria kualitas produk yang dikembangkan adalah sebagai berikut:

1. Data berupa skor penilaian dari ahli materi pembelajaran dan ahli media dan yang diperoleh dari angket mahasiswa diubah menjadi data interval. Dalam angket disediakan lima pilihan untuk memberikan tanggapan tentang kualitas produk yang dikembangkan, yaitu: sangat baik (5), baik (4), cukup (3), kurang (2), dan sangat kurang (1).

\section{Tabel 1.}

Konversi Data Kuantitatif ke Data Kualitatif dengan Skala Lima

\begin{tabular}{|c|c|c|}
\hline Nilai & Skor & Kriteria \\
\hline $\mathrm{A}$ & $\mathrm{X}>\mathrm{Xi}+1,8 \mathrm{SBi}$ & Sangat Baik \\
\hline $\mathrm{B}$ & $\mathrm{Xi}+0,6 \mathrm{SBi}<\mathrm{X} \leq \mathrm{Xi}+1,8 \mathrm{SBi}$ & Baik \\
\hline $\mathrm{C}$ & $\mathrm{Xi}-0,6 \mathrm{SBi}<\mathrm{X} \leq \mathrm{Xi}+0,6 \mathrm{SBi}$ & Cukup \\
\hline $\mathrm{D}$ & $\mathrm{Xi}-1,8 \mathrm{SBi}<\mathrm{X} \leq \mathrm{Xi}-0,6 \mathrm{SBi}$ & Kurang \\
\hline $\mathrm{E}$ & $\mathrm{X} \leq \mathrm{Xi}-1,8 \mathrm{SBi}$ & Sangat Kurang \\
\hline
\end{tabular}

Dalam penelitian ini ditetapkan nilai kelayakan produk minimal "C" dengan kategori "cukup", sebagai hasil penilaian baik dari ahli materi dan ahli media maupun mahasiswa. Jika hasil penilaian akhir secara keseluruhan pada aspek pembelajaran aspek isi/materi, aspek efektifitas dan penyajian dengan minimal "C" (cukup), maka produk hasil pengembangan tersebut sudah layak digunakan.

2. Untuk menghitung skor rata-rata dalam penilaian terhadap produk yang telah dikembangkan digunakan rumus:

$$
\bar{X}=\frac{\sum X}{n}
$$

Keterangan:

$\mathrm{X}=$ Skor rata-rata $\sum \mathrm{X}=$ Jumlah skor

$\mathrm{n}=$ Jumlah responden

Skor yang diperoleh, kemudian dikonversikan menjadi data kualitatif skala lima.

Tabel 2.

Panduan Konversi Data Kuantitatif ke Data Kualitatif dengan Skala Lima 
TSAQOFIYA: Jurnal Pendidikan Bahasa dan Sastra, 3 (1), 2021

\begin{tabular}{|c|c|c|}
\hline Skor & Interval Skor & Kategori \\
\hline 5 & $\mathrm{X}>4,21$ & Sangat Baik \\
\hline 4 & $3,40<\mathrm{X} \leq 4,21$ & Baik \\
\hline 3 & $2,60<\mathrm{X} \leq 3,40$ & Cukup \\
\hline 2 & $1,79<\mathrm{X} \leq 2,60$ & Kurang \\
\hline 1 & $\mathrm{X} \leq 1,79$ & Sangat Kurang \\
\hline
\end{tabular}

\section{Pembahasan}

\section{Analisis Masalah dalam Pembelajaran Bahan Ajar di IAIN Salatiga}

Penelitian ini diawali dengan analisis masalah dan kebutuhan dalam pembelajaran mata kuliah Bahasa Arab di IAIN Salatiga. Peneliti melakukan wawancara terhadap para dosen yang mengajar mata kuliah ini dan kepada mahasiswa yang sudah pernah mengambil mata kuliah ini. Selain itu, peneliti juga melakukan kajian terhadap silabus dan dokumen kurikulum yang ada.

Berdasarkan hal itu, ada beberapa masalah yang berkaitan dengan pengembangkan pembelajaran mata kuliah Bahasa Arab, sebagaimana berikut: pertama, belum adanya standar tujuan pembelajaran yang jelas. Tujuan yang diuraikan dalam silabus masih belum menjelaskan capaian-capaian yang terukur untuk mata kuliah Bahasa Arab. Standar kompetensi yang diharapkan untuk semua mahasiswa baru dari mata kuliah ini juga belum jelas. Kurang adanya keterkaitan antara kompetensi dan bahasan materi. Selain itu, belum ada keterkaitan tujuan mata kuliah dengan tujuan institut.

Kedua, materi hanya terfokus pada kaidah nahwu. Materi yang diajarkan pada mata kuliah Bahasa Arab hanyalah bab-bab dalam ilmu Nahwu. Materi ini merupakan salah 1 bagian SKS dalam program Studi Intensif Bahasa Arab (SIBA) yang waktu itu diselenggarakan oleh Unit Pengembangan Bahasa (UPB). Materi lain seperti kalâm, muthâla'ah dan insya' belum diakomodir dalam mata kuliah ini setelah berhentinya program SIBA dan dikembalikannya mata kuliah Bahasa Arab ke fakultas.

Ketiga, materi kurang dekat dengan mahasiswa dan kurang membangkitkan minat dan motivasi belajar.Materi yang hanya berkaitan dengan ilmu Nahwu membuat para mahasiswa merasa kesulitan dan jenuh.Selain itu, materi yang ada kurang memberi ruang bagi mahasiswa untuk memperoleh materi Bahasa Arab secara utuh dan yang lebih komunikatif.

Keempat, belum adanya buku pedoman yang baku. Dalam silabus yang ada, buku pedoman masih mengacu kepada buku ajar yang dipakai saat program SIBA dan 
hanya mengambil aspek nahwu-nya saja, sehingga para mahasiswa dan dosen masih kebingungan jika masih menggunakan buku pedoman itu.

Kelima, metode pembelajaran masih kurang variatif.Pokok-pokok materi bahasan yang hanya berkaitan dengan ilmu Nahwu membuat ruang gerak dosen untuk mengembangkan metode pembelajaran menjadi terbatas.Metode klasik dengan grammer translation method masih sering menjadi andalan.Hal ini juga menyebabkan munculnya kebosanan bagi para mahasiswa.

\section{Identifikasi Kebutuhan Pengembangan Bahan Ajar Bahasa Arab di IAIN Salatiga}

Berdasarkan uraian permasalahan di atas, ada beberpa kebutuhan dalam pengembangan Bahan Ajar Bahasa Arab di IAIN Salatiga, di antaranya sebagai berikut:

Pertama, menentukan standar kompetensi dan capaian-capaian terukur dari mata kuliah ini. Tujuan dalam suatu kurikulum merupakan unsur pertama yang harus dirumuskan sebelum unsur-unsur yang lain termasuk materi. Tujuan mata kuliah Bahasa Arab perlu diuraikan dalam standar kompetensi dan capaian-capaian perkuliahan.Hal ini didasarkan pada landasan-landasan pengembangan tertentu, termasuk relevansi dengan kebutuahan mahasiswa dan lembaga.

Kedua, materi yang yang menunjang kompetensi dan sesuai dengan visi misi lembaga. Visi dari IAIN Salatiga yaitu "Tahun 2030 Menjadi Rujukan Studi IslamIndonesia bagi Terwujudnya Masyarakat Damai Bermartabat". Berdasarkan visi itulah seharusnya tujuan dari pendidikan di lembaga dan khususnya pada setiap mata kuliah dikembangkan.Mata kuliah Bahasa Arab juga perlu dikembangkan dengan mengacu pada visi lembaga tersebut.

Ketiga, bahan ajar yang berisi materi yang dekat dengan mahasiswa dan mencakup kemampuan komunikatif.Bahan ajar Bahasa Arab yang dikembangkan yang diharapkan oleh mahasiswa adalah materi yang dekat dengan kehidupan mereka sehari-hari sehingga tidak abstrak. Misalnya yaitu materi-materi yang dekat dengan dunia kampus. Selain itu, materi yang dikembangkan diharapkan menunjang kepada kemampuan komunikatif Bahasa Arab yang kekinian.

Keempat, bahan ajar yang memasukkan unsur Bahasa Arab yang lain dan 4 kemahiran Bahasa Arab dalam materi. Bahan ajar Bahasa Arab yang dibutuhkan yaitu bahan ajar yang mencakup semua kemahiran Bahasa Arab (istimâ', kalâm, qirâ'ah dan 
kitâbah). Selain unsur-unsur Bahasa seperti shaut (suara), mufradât (kosa kata) dan qawâ'id (kaidah Bahasa Arab).

\section{Pengembangan Desain Produk Bahan Ajar Bahasa Arab di IAIN Salatiga}

Pada tahapan ini, peneliti mencoba membuat desain buku ajar Bahasa Arab berdasarkan kebutuhan-kebutuhan yang telah diuraikan di atas. Materi dikembangkan dengan menggunakan pendekatan utuh atau all in one system yang dalam Bahasa Arab diistilahkan dengan nadzariyât al-wahhdah yaitu materi Bahasa Arab ditampilkan secara komprehensif dalam setiap bab. Masing-masing bab akan mencakup pembelajaran untuk empat keterampilan berbahasa beserta pembelajaran tata bahasanya. Secara rinci, desain pengembangan bahan ajar pada penelitian ini melalui tiga tahap yaitu:

1. Menetapkan tujuan mata kuliah

Tujuan dari mata kuliah ini diuraikan dalam capaian pembelajaran sebagimana berikut:

"Mahasiswa memiliki keterampilan dasar berbahasa Arab sererti menyimak Bahasa Arab dasar, berbicaa Bahasa Arab dasar, membaca Bahasa Arab dasar dan menulis Bahasa Arab dasar serta mengenal kaidah dasar Bahasa Arab. Selain itu, mahasiswa dapat memahami nilai-nilai Islam-Indonesia".

Adapun kemampuan yang diharapkan adalah sebagimana berikut:

a. Mahasiswa mampu memahami ungkapan-ungkapan sederhana Bahasa Arab yang didengarkannya.

b. Mahasiswa mampu mempraktikkan percakapan Bahasa Arab sederhana dalam kehidupan sehari-hari.

c. Mahasiswa mampu memahami teks sederhana Bahasa Arab tentang kehidupan kampus dan mengambil nilai-nilai Islam-Indonesia dari bacaan.

d. Mahasiswa menguasai 250 kosakata baru baik isim maupun fi'il.

e. Mahasiswa mampu menulis Bahasa Arab dengan benar.

f. Mahasiswa mampu memahami kaidah dasar Bahasa Arab dan menganalisis kedudukan kata dalam kalimat-kalimat sederhana.

2. Menetapkan materi/bahan ajar yang akan dipelajari

Berdasarkan tujuan-tujuan yang diuraikan di atas, materi ajar dijabarkan dalam tema-tema sebagai berikut: 
TSAQOFIYA: Jurnal Pendidikan Bahasa dan Sastra, 3 (1), 2021

Tabel 3.

Desain Materi dan Tema-Tema dalam Buku Ajar

\begin{tabular}{|c|c|c|}
\hline $\begin{array}{c}\text { Pelajaran } \\
\text { ke: }\end{array}$ & Tema & Materi \\
\hline 1 & $\begin{array}{c}\text { Melanjutkan } \\
\text { Studi ke } \\
\text { Perguruan Tinggi } \\
\text { (الالتحاق بالجامعنة) }\end{array}$ & $\begin{array}{ll}\text { - } & \text { Istima' tentang ungkapan-ungkapan untuk } \\
\text { berkenalan. } \\
\text { - } \quad \text { Percakapan untuk berkenalan. } \\
\text { - } \quad \text { Teks bacaan dengan tema “IAIN Salatiga”. } \\
\text { - } \quad \text { Kosakata tentang Perkenalan dan } \\
\text { Perguruan Tinggi. } \\
\text { - } \quad \text { Pembagian kalimat (isim, fi'il dan huruf). } \\
\text { - } \quad \text { Menulis } 1 \text { mahfudzat tentang ilmu. }\end{array}$ \\
\hline 2 & $\begin{array}{c}\text { Tempat tinggal } \\
\text { (السكن) }\end{array}$ & 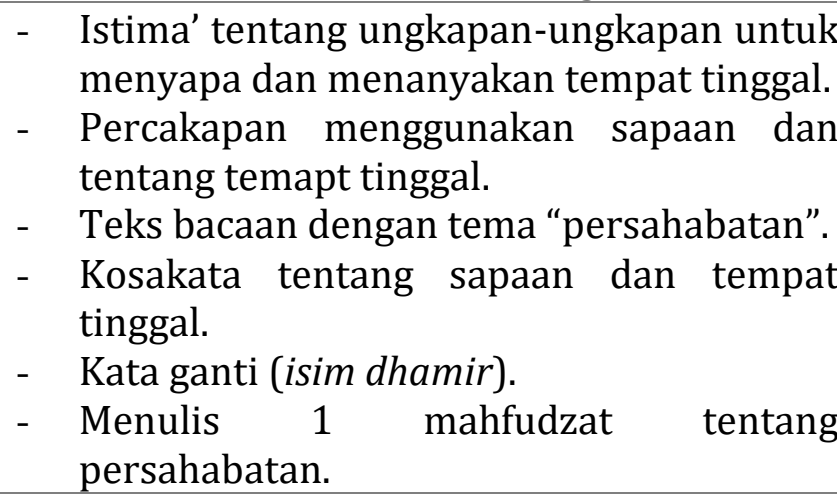 \\
\hline 3 & $\begin{array}{l}\text { Kantin } \\
\text { (في المقصف) }\end{array}$ & $\begin{array}{l}\text { - Istima' tentang ungkapan-ungkapan untuk } \\
\text { menawarkan dan meminta bantuan. } \\
\text { - Percakapan untuk menawarkan dan } \\
\text { meminta bantuan di kantin. } \\
\text { - Teks bacaan dengan tema "mencegah } \\
\text { lebih baik daripada mengobati". } \\
\text { - Kosakata tentang menawarkan dan } \\
\text { meminta bantuan, kantin dan makanan. } \\
\text { - Isim mudzkkar dan mu`annats. } \\
\text { - Menulis } 1 \text { mahfudzat tentang kesehatan. }\end{array}$ \\
\hline 4 & $\begin{array}{c}\text { Perpustakaan } \\
\text { (في المكتبة) }\end{array}$ & 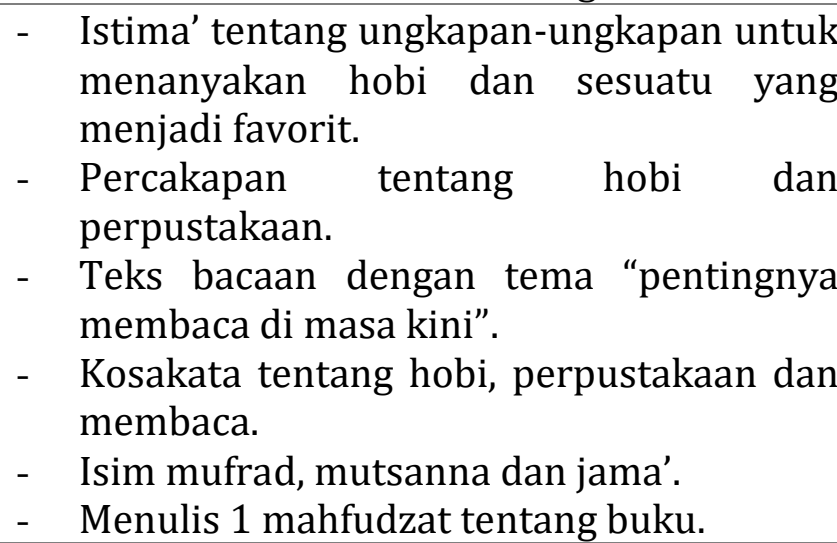 \\
\hline 5 & $\begin{array}{c}\text { Kegiatan } \\
\text { Mahasiswa } \\
\text { (أنشطة الطلبة) }\end{array}$ & $\begin{array}{ll}\text { - } & \text { Istima' tentang kata Tanya. } \\
\text { - } & \text { Percakapan tentang kegiatan sehari-hari. } \\
\text { - } & \text { Teks bacaan dengan tema "kegiatan } \\
\text { mahasiswa sehari-hari di kampus". } \\
\text { - } \quad \text { Kosakata tentang kata tanya, dan kegiatan } \\
\text { sehar-hari. }\end{array}$ \\
\hline
\end{tabular}




\begin{tabular}{|c|c|c|}
\hline & & $\begin{array}{l}\text { - Pembagian fi'il (madhi, mudhari' dan } \\
\text { amar). } \\
\text { - Menulis } 1 \text { mahfudzat tentang pentingnya } \\
\text { memanfaatkan waktu. }\end{array}$ \\
\hline 6 & $\begin{array}{c}\text { Hari Libur } \\
\text { (العطلة) }\end{array}$ & $\begin{array}{l}\text { - Istima' tentang ungkapan-ungkapan untuk } \\
\text { menyampaikan ucapan selamat. } \\
\text { - } \quad \text { Percakapan tentang hari libur. } \\
\text { - Teks bacaan dengan tema “tempat-tempat } \\
\text { wisata di Jawa Tengah". } \\
\text { - } \quad \text { Kosakata tentang ucapan selamat, hari } \\
\text { libur dan tempat-tempat wisata. } \\
\text { - } \quad \text { Jumlah Ismiyah dan Fi'liyah. } \\
\text { - Menulis mahfudzat tentang cinta tanah air } \\
\text { dan Indonesia. }\end{array}$ \\
\hline
\end{tabular}

3. Merumuskan evaluasi/penilaian

Penilaian yang digunakan untuk mengevaluasi materi yaitu dengan tes tertulis, ujian lisan, penugasan membuat produk dan unjuk kerja.

\section{Validasi Desain Produk Bahan Ajar Bahasa Arab di IAIN Salatiga}

Validasi merupakan proses permintaan pengesahan atau persetujuan terhadap produk yang telah dibuat peneliti. Validasi ini dilakukan untuk menilai sejauh mana produk yang dihasilkan dapat digunakan di dalam proses pembelajaran. Validasi dilakukan dalam dua hal; pertama validasi oleh ahli desain untuk melihat sejauh mana kebenaran dan kesesuaian desain buku ajar dan kedua validasi mengenai materi untuk mengetahui dan menilai kebenaran konsep serta kesesuaian materi dengan tujuan pembelajaran yang hendak dicapai.

Buku ajar Bahasa Arab berbasis pada nilai-nilai Islam-Indonesia yang telah selesai disusun menghasilkan produk awal. Selanjutnya peneliti mengkonsultasikan draf buku ajar kepada ahli yang mempunyai kompetensi pada bidang tersebut untuk mengevaluasi desain serta isi atau cakupan materi.

Dalam penentuan ahli, peneliti menggunakan dua orang ahli. Satu ahli yang menguasai dalam isi materi yaitu Dra. Ulfah Susilawati, M.S.I., (Koordinator Bahasa Arab IAIN Salatiga). Sedang untuk ahli yang satunya peneliti meminta kepada Arif Billah, M.Pd. sebagai ahli yang lebih kompeten dalam bidang desain bukunya.

\section{Validasi Desain Buku Ajar}


TSAQOFIYA: Jurnal Pendidikan Bahasa dan Sastra, 3 (1), 2021

Adapun hasil penilaian ahli desain terhadap buku ajar yang dikembangkan dari aspek tampilan dan penyajiannya adalah sebagai berikut:

Tabel 4.

Data Hasil Penilaian Ahli Desain pada Aspek Tampilan

\begin{tabular}{llrc}
\hline No & Butir & Skor & Kategori \\
\hline $\mathbf{1}$ & Desain cover & 4 & Baik \\
\hline $\mathbf{2}$ & Tata letak (layout) & 4 & Baik \\
\hline $\mathbf{3}$ & Ukuran huruf & 4 & Baik \\
$\mathbf{4}$ & Pemilihan bahasa & 4 & Baik \\
\hline $\mathbf{5}$ & $\begin{array}{l}\text { Penggunaan kata dan } \\
\text { istilah }\end{array}$ & 4 & Baik \\
\hline $\mathbf{6}$ & Keterbacaan tulisan & 3 & Cukup \\
\hline $\mathbf{7}$ & Kejelasan cetakan & 5 & Sangat Baik \\
$\mathbf{8}$ & Kemudahan petunjuk & 4 & Baik \\
\hline$\quad$ Jumlah & & 32 \\
\hline & Rata-rata & & Baik \\
\hline & kategori & &
\end{tabular}

Tabel 5.

Data Hasil Penilaian Ahli Desain pada Aspek Penyajian

\begin{tabular}{llcc}
\hline No & Butir & Skor & Kategori \\
\hline 1 & Konsistensi sistematika penyajian & 4 & Baik \\
\hline 2 & Keruntutan sajian & 3 & Cukup \\
\hline 3 & $\begin{array}{l}\text { Keseimbangan sajian materi } \\
\text { (substansi) antarbab dan antarsubbab }\end{array}$ & 4 & Baik \\
\hline 4 & Sistematika dalam bab & 4 & Baik \\
\hline 5 & Ragam latihan & 3 & Cukup \\
\hline 6 & Interaktif-partisipatif & 4 & Baik \\
\hline 7 & $\begin{array}{l}\text { Mendorong keterlibatan peserta didik } \\
\text { untuk belajar mandiri dan kelompok } \\
\text { yang interaktif dengan sumber belajar } \\
\text { Mendorong berfikir kritis, kreatif, dan } \\
\text { inovatif }\end{array}$ & 4 & Baik \\
\hline 9 & $\begin{array}{l}\text { Ketertautan antarbab, subbab, dan } \\
\text { alinea }\end{array}$ & 4 & Baik \\
\hline 10 & $\begin{array}{l}\text { Keutuhan dan keterpaduan makna } \\
\text { dalam bab, subbab, alinea. }\end{array}$ & 3 & Cukup \\
\hline$\quad \quad$ Jumlah & & 36 \\
\hline & $\quad$ Rata-rata & Bategori \\
\hline & $\quad$ & & 3,6 \\
\hline
\end{tabular}

Hasil penilaian ahli desain terhadap produk yang dikembangkan pada aspek tampilan (dapat dilihat pada tabel 4) dengan skor penilaian rata-rata 4 dengan kategori "baik" dan aspek penyajian (dapat dilihat pada tabel 5) dengan skor penilaian rata-rata 3,6 dengan kategori "baik". 
TSAQOFIYA: Jurnal Pendidikan Bahasa dan Sastra, 3 (1), 2021

\section{Validasi Materi Buku Ajar}

Hasil dari validasi ahli materi terhadap buku ajar yang dikembangkan dari aspek pembelajaran dan aspek isi atau materi adalah sebagai berikut:

Tabel 6.

Data Hasil Penilaian Ahli Materi pada Aspek Pembelajaran

\begin{tabular}{llcc}
\hline No & Butir & Skor & Kategori \\
\hline 1 & Kesesuaian materi dengan capaian pembelajaran & 4 & Baik \\
\hline 2 & $\begin{array}{l}\text { Kesesuaian kemampuan yang diharapkan } \\
\text { dengan capaian pembelajaran }\end{array}$ & 4 & Baik \\
\hline 3 & $\begin{array}{l}\text { Kesesuaian materi dengan kemampuan yang } \\
\text { diharapkan }\end{array}$ & 4 & Baik \\
\hline 4 & Sistematika penyajian materi & 5 & $\begin{array}{c}\text { Sangat } \\
\text { Baik }\end{array}$ \\
\hline 5 & Kejelasan petunjuk belajar & 4 & Baik \\
\hline 6 & Kebenaran uraian materi & 4 & Baik \\
\hline 7 & Kejelasan sasaran program & 3 & Cukup \\
\hline 8 & Pemilihan strategi belajar & 5 & $\begin{array}{c}\text { Sangat } \\
\text { Baik }\end{array}$ \\
\hline 9 & $\begin{array}{l}\text { Pemberian contoh-contoh dalam penyajian } \\
\text { materi }\end{array}$ & 3 & Cukup \\
\hline 10 & Pemberian latihan untuk pemahaman materi & 3 & Cukup \\
\hline$\quad$ Jumlah & & 39 \\
\hline & Rata-rata & & 3,9 \\
\hline & kategori & & Baik \\
\hline
\end{tabular}

Tabel 7.

Data Hasil Penilaian Ahli Materi pada Aspek Isi

\begin{tabular}{llcc}
\hline No & Butir & Skor & Kategori \\
\hline 1 & Materi mudah dipahami & 4 & Baik \\
\hline 2 & Kebenaran isi materi yang disajikan & 4 & Baik \\
\hline 3 & Kejelasan uraian materi & 4 & Baik \\
\hline 4 & Kesesuaian materi dengan mahasiswa & 5 & $\begin{array}{c}\text { Sangat } \\
\text { Baik }\end{array}$ \\
& & & Baik \\
\hline 5 & Kesesuaian contoh dengan materi & 4 & Baik \\
\hline 6 & Kesesuaian latihan dengan materi & 4 & Cukup \\
\hline 7 & Konsistensi penyajian & 3 & Baik \\
\hline 8 & $\begin{array}{l}\text { Penggunaan bahasa yang tepat dalam menjelaskan } \\
\text { materi }\end{array}$ & 4 & Baik \\
\hline 9 & Variasi bentuk soal & 4 & Baik \\
\hline 10 & Tingkat kesulitan soal Jumlah & 4 & 40 \\
\hline & $\quad$ Rata-rata & & 4,0 \\
\hline & $\quad$ kategori & & Baik \\
\hline
\end{tabular}


Hasil penilaian ahli materi terhadap produk yang dikembangkan pada aspek pembelajaran (dapat dilihat pada tabel 6) dengan skor penilaian rata-rata 3,9 dan aspek isi/materi (dapat dilihat pada tabel 7) dengan skor penilaian ratarata 4.

\section{Revisi Desain Produk Bahan Ajar Bahasa Arab di IAIN Salatiga}

Setelah adanya validasi desain dan materi dari ahli, tahap berikutnya adalah revisi desain produk bahan ajar Bahasa Arab berbasis nilai-nilai Islam di Indonesia berdasarkan masukan, komentar dan koreksi dari ahli. Hal ini dilakukan supaya bahan ajar sudah siap diuji cobakan penggunaannya dalam pembelajaran.

Beberapa di antara hasil revisi setelah mendapatkan masukan dari ahli desain adalah sebagai berikut:

Tabel 8.

Hasil Revisi Desain Produk dari Aspek Desain

\begin{tabular}{lll}
\hline No & \multicolumn{1}{c}{ Desain awal } & \multicolumn{1}{c}{ Hasil revisi } \\
\hline 1 & $\begin{array}{l}\text { Cover masih belum menunjukkan ciri } \\
\text { khas yang mewakili objek, isi dan } \\
\text { tujuan di mana buku ini akan } \\
\text { digunakan }\end{array}$ & $\begin{array}{l}\text { Cover didesain ulang dengan ciri } \\
\text { khas yang mewakili objek, isi dan } \\
\text { tujuan di mana buku ini akan } \\
\text { digunakan }\end{array}$ \\
\hline 2 & $\begin{array}{l}\text { Ukuran kertas yang digunakan } \\
\text { adalah A5 atau setngah A4 sehingga } \\
\text { terlihat terlalu kecil }\end{array}$ & Ukuran kertas dirubah menjadi B5 \\
\hline 3 & $\begin{array}{l}\text { Ukuran font juga terlalu kecil karena } \\
\text { mengikuti ukuran kertas }\end{array}$ & Ukuran font diperbesar \\
\hline 4 & $\begin{array}{l}\text { Jenis font yang digunakan kurang } \\
\text { jelas dan kurang begitu menarik } \\
\text { untuk dibaca }\end{array}$ & Jenis font diganti dengan yang lebih \\
jelas dan menarik untuk dibaca
\end{tabular}

Sedangkan beberapa di antara hasil revisi setelah mendapatkan masukan dari ahli materi adalah sebagai berikut:

Tabel 9.

Hasil Revisi Desain Produk dari Aspek Materi

\begin{tabular}{llc}
\hline No & \multicolumn{1}{c}{ Desain awal } & Hasil revisi \\
\hline 1 & $\begin{array}{l}\text { Materi dalam bacaan beberapa masih } \\
\text { ada kesalahan dalam pemilihan kata }\end{array}$ & Revisi beberapa kata dalam bacaan \\
& & \\
\hline
\end{tabular}


TSAQOFIYA: Jurnal Pendidikan Bahasa dan Sastra, 3 (1), 2021

\begin{tabular}{|c|c|c|}
\hline 2 & $\begin{array}{l}\text { Terdapat beberapa kesalahan dalam } \\
\text { pengetikan }\end{array}$ & $\begin{array}{l}\text { Revisi beberapa pengetikan yang } \\
\text { masik salah }\end{array}$ \\
\hline 3 & $\begin{array}{l}\text { Petunjuk pada setiap sub bab untuk } \\
\text { diperjelas lagi }\end{array}$ & $\begin{array}{l}\text { Memperjelas petunjuk belajar pada } \\
\text { setiap sub bab }\end{array}$ \\
\hline 4 & $\begin{array}{l}\text { Petunjuk pada latihan-latihan untuk } \\
\text { diperjelas lagi }\end{array}$ & $\begin{array}{l}\text { Memperjelas petunjuk pada soal- } \\
\text { soal latihan }\end{array}$ \\
\hline 5 & $\begin{array}{l}\text { Materi dalam latihan tata bahasa belum } \\
\text { banyak disesuaikan dengan materi- } \\
\text { materi diatasnya }\end{array}$ & $\begin{array}{l}\text { Materi dalam latihan tata bahasa } \\
\text { disesuaikan dengan materi-materi } \\
\text { diatasnya }\end{array}$ \\
\hline
\end{tabular}

\section{Uji Coba Penggunaan Desain Produk Bahan Ajar Bahasa Arab di IAIN Salatiga}

Desain bahan ajar yang sudah di desain dicoba digunakan dalam pembelajaranBahasa Arab. Untuk mengetahui respon mahasiswa terhadap bahan ajar yang dikembangkan, peneliti melibatkan 100 mahasiswa untuk menilai buku ajar Bahasa Arab yang telah dikembangkan. Angket diberikan dua kali yang terbagi menjadi kelas kecil untuk pembagian pertama dan kelas besar pada pembagian kedua yang terdiri dari 100 orang mahasiswa.

Angket yang diberikan kepada mahasiswa meliputi aspek pembelajaran, aspek isi/materi, aspek tampilan, dan aspek penyajian.Dalam hal ini data yang dilaporkan adalah hasil respon mahasiswa yang peneliti dapatkan dari kelas besar. Adapun hasil angket yang diterima sebagai berikut:

\section{Aspek Pembelajaran}

Berdasarkan respon mahasiswa terhadap buku ajar dari aspek pembelajaran diperoleh nilai sebagai berikut:

Tabel 10.

Respon mahasiswa terhadap Buku Ajar pada Aspek Pembelajaran

\begin{tabular}{llcc}
\hline No & Butir & Skor & Kategori \\
\hline 1 & $\begin{array}{l}\text { Kesesuaian materi dengan capaian } \\
\text { pembelajaran }\end{array}$ & 3,85 & Baik \\
\hline 2 & $\begin{array}{l}\text { Kesesuaian kemampuan yang } \\
\text { diharapkan dengan capaian } \\
\text { pembelajaran }\end{array}$ & 3,85 & Baik \\
\hline 3 & $\begin{array}{l}\text { Kesesuaian materi dengan } \\
\text { kemampuan yang diharapkan }\end{array}$ & 3,95 & Baik \\
\hline 4 & Sistematika penyajian materi & 4 & Baik \\
\hline 5 & Kejelasan petunjuk belajar & 4,25 & $\begin{array}{c}\text { Sangat } \\
\text { Baik }\end{array}$ \\
\hline 6 & Kebenaran uraian materi & 4,2 & Baik \\
\hline
\end{tabular}


TSAQOFIYA: Jurnal Pendidikan Bahasa dan Sastra, 3 (1), 2021

\begin{tabular}{llcc}
\hline 7 & Kejelasan sasaran program & 4,15 & Baik \\
\hline 8 & Pemilihan strategi belajar & 4,15 & Baik \\
\hline 9 & $\begin{array}{l}\text { Pemberian contoh-contoh dalam } \\
\text { penyajian materi }\end{array}$ & 3,85 & Baik \\
\hline 10 & $\begin{array}{l}\text { Pemberian latihan untuk pemahaman } \\
\text { materi }\end{array}$ & 4 & Baik \\
\hline \multicolumn{2}{l}{ Jumlah } & 40,25 \\
\hline & Rata-rata & 4,025 \\
\hline & kategori & Baik \\
\hline
\end{tabular}

Berdasarkan pada tabel 10 diketahui bahwa tanggapan mahasiswa terhadap kualitas produk dilihat dari aspek pembelajaran adalah rerata 4,025.

\section{Aspek Isi/Materi}

Respon mahasiswa terhadap buku ajar dari aspek isi atau materi diperoleh nilai sebagai berikut:

Tabel 11.

Data Respon Mahasiswa terhadap Buku Ajar pada Aspek Isi

\begin{tabular}{llcc}
\hline No & Butir & Skor & Kategori \\
\hline 1 & Materi mudah dipahami & 4,05 & Baik \\
\hline 2 & $\begin{array}{l}\text { Kebenaran isi materi yang } \\
\text { disajikan }\end{array}$ & 3,95 & Baik \\
\hline 3 & Kejelasan uraian materi & 4 & Baik \\
\hline 4 & $\begin{array}{l}\text { Kesesuaian materi dengan } \\
\text { mahasiswa }\end{array}$ & 4,25 & Sangat Baik \\
\hline 5 & $\begin{array}{l}\text { Kesesuaian contoh dengan } \\
\text { materi }\end{array}$ & 4,1 & Baik \\
\hline 6 & $\begin{array}{l}\text { Kesesuaian latihan dengan } \\
\text { materi }\end{array}$ & 4 & Baik \\
\hline 7 & Konsistensi penyajian & 4,15 & Cukup \\
\hline 8 & $\begin{array}{l}\text { Penggunaan bahasa yang tepat } \\
\text { dalam menjelaskan materi }\end{array}$ & 4,25 & Sangat Baik \\
\hline 9 & Variasi bentuk soal & 4,05 & Baik \\
\hline 10 & Tingkat kesulitan soal & 4,15 & Baik \\
\hline$\quad$ Jumlah & & 40,95 \\
\hline$\quad$ Rata-rata & & 4,095 \\
\hline$\quad$ kategori \\
\hline
\end{tabular}

Berdasarkan pada tabel 11 diketahui bahwa tanggapan mahasiswa terhadap kualitas produk dilihat dari aspek isi/materi adalah rerata 4,095.

\section{Aspek Tampilan}

Respon mahasiswa terhadap buku ajar dari aspek tampilan diperoleh nilai sebagai berikut: 
TSAQOFIYA: Jurnal Pendidikan Bahasa dan Sastra, 3 (1), 2021

Tabel 12.

Data Respon Mahasiswa terhadap Buku Ajar pada Aspek Tampilan

\begin{tabular}{llcc}
\hline No & Butir & Skor & Kategori \\
\hline 1 & Desain cover & 4,25 & Sangat baik \\
\hline 2 & Tata letak (layout) & 4,15 & Baik \\
\hline 3 & Ukuran huruf & 3,65 & Baik \\
\hline 4 & Pemilihan bahasa & 3,95 & Baik \\
\hline 5 & $\begin{array}{l}\text { Penggunaan kata dan } \\
\text { istilah }\end{array}$ & 4,25 & Sangat Baik \\
\hline 6 & Keterbacaan tulisan & 4,15 & Baik \\
\hline 7 & Kejelasan cetakan & 4,25 & Sangat Baik \\
\hline 8 & Kemudahan petunjuk & 4,1 & Baik \\
\hline \multicolumn{2}{c}{ Jumlah } & & 32.75 \\
\hline$\quad$ Rata-rata & & 4,0938 \\
\hline$\quad$ kategori & & Baik \\
\hline
\end{tabular}

Berdasarkan pada tabel 12 diketahui bahwa tanggapan mahasiswa terhadap kualitas produk dilihat dari aspek tampilan adalah rerata 4,0938.

\section{Aspek Penyajian}

Respon mahasiswa terhadap buku ajar dari aspek penyajian diperoleh hasil sebagai berikut:

Tabel 13.

Data Respon Mahasiswa terhadap Buku Ajar pada Aspek Penyajian

\begin{tabular}{llcc}
\hline No & Butir & Skor & Kategori \\
\hline 1 & Konsistensi sistematika penyajian & 4,25 & $\begin{array}{c}\text { Sangat } \\
\text { Baik }\end{array}$ \\
\hline 2 & Keruntutan sajian & 4,15 & Baik \\
\hline 3 & $\begin{array}{l}\text { Keseimbangan sajian materi } \\
\text { (substansi) antarbab dan } \\
\text { antarsubbab }\end{array}$ & 3,95 & Baik \\
\hline 4 & Sistematika dalam bab & 3,95 & Baik \\
\hline 5 & Ragam latihan & 4 & Baik \\
\hline 6 & Interaktif-partisipatif & 4,15 & Baik \\
\hline 7 & $\begin{array}{l}\text { Mendorong keterlibatan peserta } \\
\text { didik untuk belajar mandiri dan }\end{array}$ & 3,8 & Baik \\
& $\begin{array}{l}\text { kelompok yang interaktif dengan } \\
\text { sumber belajar }\end{array}$ & & \\
\hline 8 & $\begin{array}{l}\text { Mendorong berfikir kritis, kreatif, } \\
\text { dan inovatif }\end{array}$ & 4,3 & Sangat \\
\hline 9 & $\begin{array}{l}\text { Ketertautan antarbab, subbab, dan } \\
\text { alinea }\end{array}$ & 4,1 & Baik \\
\hline 10 & $\begin{array}{l}\text { Keutuhan dan keterpaduan makna } \\
\text { dalam bab, subbab, alinea. }\end{array}$ & 4,15 & Baik \\
\hline & $\quad$ Jumlah & 40,8 \\
\hline & $\quad$ Rata-rata & 4,08 \\
\hline
\end{tabular}


TSAQOFIYA: Jurnal Pendidikan Bahasa dan Sastra, 3 (1), 2021

\begin{tabular}{rr}
\hline kategori & Baik \\
\hline
\end{tabular}

Berdasarkan pada tabel 13 diketahui bahwa tanggapan mahasiswa terhadap kualitas produk dilihat dari aspek penyajian adalah rerata 4,08.

Dengan demikian, berdasar pada tabel 10-13 secara keseluruhan respon atau tanggapan mahasiswa terhadap Buku Ajar Bahasa Arab Berbasis pada NilaiNilai Islam-Indonesia di IAIN Salatiga yang dikembangkan dilihat dari aspek pembelajaran dengan skor rata-rata 4,025, aspek isi/materi dengan skor ratarata 4,095, aspek tampilan dengan skor rata-rata 4,098 dan aspek penyajian dengan skor rata-rata 4,08, maka rerata skor secara keseluruhan adalah 4,075. Secara visual hasil tanggapan mahasiswa terhadap kualitas produk dapat dilihat pada tabel 13 berikut:

Tabel 14.

Skor Hasil Penilaian Tanggapan Mahasiswa Pada Keempat Aspek Pengembangan Buku Ajar Bahasa Arab Berbasis Nilai-nilai Islam Indonesia di IAIN Salatiaga

\begin{tabular}{cc}
\hline Aspek Penilaian & Rata-rata \\
\hline Pembelajaran & 4,025 \\
\hline Isi/materi & 4,095 \\
\hline Tampilan & 4,098 \\
\hline Penyajian & 4,08 \\
\hline Rerata & 4,075 \\
\hline Kategori & Baik \\
\hline
\end{tabular}

Dengan demikian, buku ajar Bahasa Arab berbasis pada nilai-nilai IslamIndonesia ini layak digunakan sebagai bahan ajar dalam mata kuliah Bahasa Arab di IAIN Salatiga.

\section{Desain Akhir Produk Bahan Ajar Bahasa Arab di IAIN Salatiga}

Setalah diuji cobakan, tahap berikutnya adalah mendesai akhir produk bahan ajara Bahasa Arab berbasis pada nilai-nilai Islam Indonesia di IAIN Salatiga. Berikut ini adalah gambaran desain akhir produk:

Gambar 1. Cover Buku Ajar Bahasa 
TSAQOFIYA: Jurnal Pendidikan Bahasa dan Sastra, 3 (1), 2021

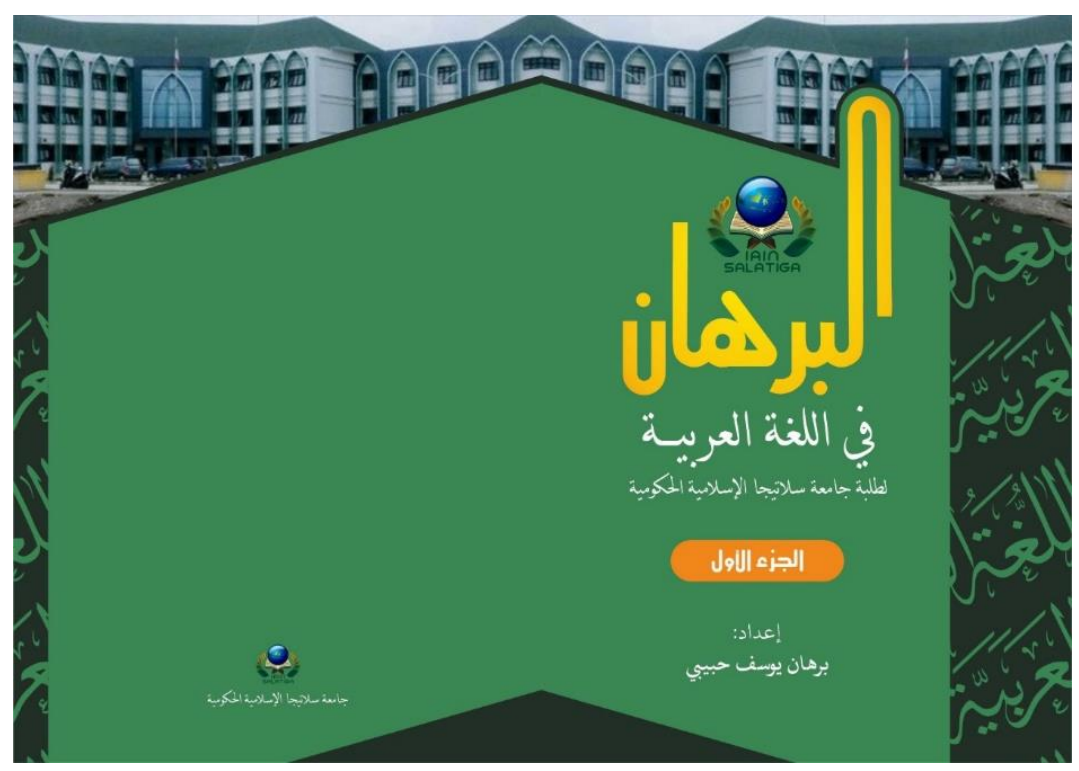

Gambar 2. Bagian Daftar Isi

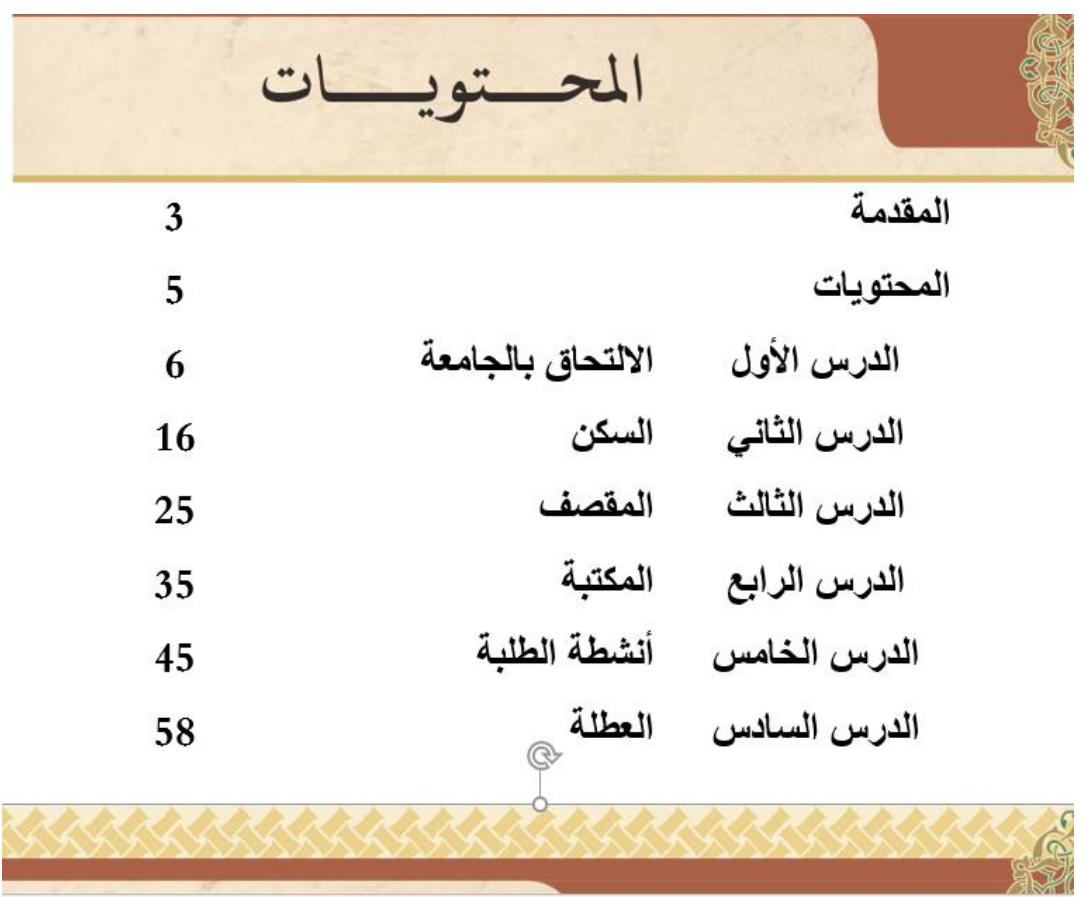

\section{Kesimpulan}

Berdasarkan hasil penelitian dan pembahasan, diperoleh simpulan tentang pengembangan bahan ajar Bahasa Arab berbasis pada nilai-nilai Islam Indonesia di IAIN Salatiga. Simpulan dari penelitian ini sebagaimana berikut:

Pertama, Hasil validasi ahli desain dan ahli materi serta respon mahasiswa terhadap produk buku ajar Bahasa Arab berbasis nilai-nilai Islam-Indonesia di IAIN Salatiga manunjukkan bahwa: Validasi produk buku ajar Bahasa Arab berbasis nilainilai Islam-Indonesia dari ahli desain; 1) Hasil penilaian ahli desain terhadap produk 
TSAQOFIYA: Jurnal Pendidikan Bahasa dan Sastra, 3 (1), 2021

yang dikembangkan pada aspek tampilan (dapat dilihat pada tabel 5) dengan skor penilaian rata-rata 4 dengan kategori "baik" dan 2) Hasil penilaian aspek penyajian (dapat dilihat pada tabel 6) dengan skor penilaian rata-rata 3,6 dengan kategori "baik".

Kedua, Validasi produk buku ajar Bahasa Arab berbasis nilai-nilai IslamIndonesia di IAIN Salatiga dari ahli materi menunjukkan bahwa: 1) Hasil penilaian ahli materi terhadap produk yang dikembangkan pada aspek pembelajaran (dapat dilihat pada tabel 7) dengan skor penilaian rata-rata 3,9 termasuk kategori "baik", dan 2) Hasil penilaian aspek isi/materi (dapat dilihat pada tabel 8) dengan skor penilaian rata-rata 4 termasuk kategori "baik".

Ketiga, berdasar pada tabel 11-14 secara keseluruhan respon atau tanggapan mahasiswa terhadap Buku Ajar Bahasa Arab Berbasis pada Nilai-Nilai IslamIndonesia di IAIN Salatiga yang dikembangkan dilihat dari aspek pembelajaran dengan skor rata-rata 4,025, aspek isi/materi dengan skor rata-rata 4,095, aspek tampilan dengan skor rata-rata 4,098 dan aspek penyajian dengan skor rata-rata 4,08, maka rerata skor secara keseluruhan adalah 4,075.

Keempat, buku ajar Bahasa Arab berbasis pada nilai-nilai Islam-Indonesia ini layak digunakan sebagai bahan ajar dalam mata kuliah Bahasa Arab di IAIN Salatiga.

\section{Daftar Pustaka}

Borg, W.R. and Gall, M.D. Education Research: An Introduction. London: Longman, Inc, 1983.

Dijk, Teun Adrianus Van, and Walter Kintsch. "Strategies of Discourse Comprehension," 1983.

Prastowo, A. Pengembangan Bahan Ajar Tematik. Jakarta: Kencana Predanamedia Group, 2014.

Sugiyono, Prof Dr. Metode Penelitian Kuantitatif, Kualitatif Dan R \& D. Alfabeta. Bandung, 2010.

Erlina. 2017. Jurnal Al Bayan. Pengembangan Bahan Ajar Qira'ah Terpadu bagi Mahasiswa Program Studi Pendidikan Bahasa Arab. Vol.9, No.2,Bulan Desember Tahun 2107.

Harijanto. 2007. Jurnal Didaktika. Pengembangan Bahan Ajar Untuk Peningkatan Kualitas Pembelajaran Program Pendidikan Pembelajar Sekolah Dasar.Vol.2 No. 1 Maret 2002. 
TSAQOFIYA: Jurnal Pendidikan Bahasa dan Sastra, 3 (1), 2021

Jolly, David and Rod Bolitho. 1998. A Framework for Material Writing dalam Brian Tomlinson (Ed.) Material Development in Language Teaching. Cambridge: Cambridge University Press.

Wahab, Laode Abdul. 2014. Jurnal Al-Izzah. Pengembangan Bahan Ajar Qawaid Bahasa Arab Berbasis Mind Map untuk STAIN Kendari. Vol.9, No.2 November 2014.

Rahmawati, Nur Laila. 2018. Lisania: Journal of Arabic Education and Literature. Pengembangkan Bahan Ajar Al-'Arabiyyah Li al-Athfâl (ALA) berbasis Permainan Tradisional Indonesia di STAI At-Tanwir Bojonegoro. Vol.2, No.1.Desember 2018.

Setiawan, D, Wahyuni, K, dan Prastati, T. 2007.Pengembangan bahan ajar. Jakarta: Universitas Terbuka. 